\title{
EXPERIMENTÁLNÍ MĚŘENÍ DYNAMICKÝCH ZMĚN PLOŠNÉ HMOTNOSTI SYSTÉMŮ VEGETAČNÍCH STĚN A FASÁD VLIVEM EVAPOTRANSPIRACE
}

\author{
EXPERIMENTAL MEASUREMENT OF DYNAMIC CHANGES IN THE \\ BASIS WEIGHT OF VEGETATION WALLS AND FACADES DUE TO \\ EVAPOTRANSPIRATION
}

Jan Vystrčil ${ }^{*}, 1$, Ondřej Nespěšný ${ }^{1}$, Dominik Cakl ${ }^{2}$

*jan.vystrcil@vutbr.cz

${ }^{1}$ Vysoké učení technické v Brně, Fakulta stavební, Veveří 331/95, 60200 Brno

\begin{abstract}
Abstrakt
Systémy zelených stěn a fasád jsou moderním prvkem pozemních staveb. Pro zajištění správného návrhu a funkčnosti těchto systémů $\mathrm{v}$ průběhu jejich životního cyklu je nezbytný popis jejich vlastností. Jednou ze základních vlastností fasádních a obkladových prvků je plošná hmotnost. Ta závisí na zvoleném systému provedení vegetační stěny či fasády, zvoleném množství a druhovém zastoupení vegetace a v neposlední řadě na okolních podmínkách místa instalace. Vzhledem k tomu, že se jedná o živé prvky, je nutné konstatovat, že tato vlastnost nelze vyjádřit jednou hodnotou, ale hmotnostním rozsahem. $Z$ důvodu velké odlišnosti těchto systémů od standardních obkladových či fasádních prvků jsou pro zjištění plošné hmotnosti standardní metody zkoušení nepoužitelné. Tento př́íspěvek popisuje možnou metodiku pro stanovení plošné hmotnosti systémů vegetačních fasád a jejich změn v čase.
\end{abstract}

\section{Klíčová slova}

Vegetační stěna, plošná hmotnost, experimentální měření, zkušební stand, trvale udržitelná architektura.

\section{Abstract}

Green wall and facade systems are a modern element of building construction. To ensure the correct design and functionality of these systems during their life cycle, it is necessary to describe their properties. One of the basic properties of facade and cladding elements is the basis weight. It depends on the chosen system of vegetation wall or facade, the chosen amount, and species representation of vegetation and last but not least on the surrounding conditions of the installation site. Given that these are living elements, it must be stated that this property cannot be expressed in a single value, but in a mass range. Due to the great difference between these systems and standard cladding or façade elements, standard testing methods are not applicable for determining the basis weight. This paper describes a possible methodology for determining the basis weight of vegetation facade systems and their changes over time.

\section{Key words}

Green wall, basis weight, experimental measurements, test stand, sustainable architecture, climate change.

\section{1 ÚVOD}

Dle organizace spojených národů je klimatická změna jednou z největších hrozeb lidského života [1]. Změny klimatu jsou velmi patrné v posledních deseti letech např́íc oblastmi celé naší země [2]. V návaznosti na tyto změny je kladen čím dál větší společenský a politický důraz na trvale udržitelný rozvoj společnosti. Architektura, urbanismus a stavebnictví má zásadní vliv na život lidí, a to zejména $\mathrm{v}$ urbanisticky vyspělých oblastech. V těchto souvislostech jsou velmi diskutovaná témata, jako nakládání s pitnou a dešt'ovou vodou, vliv zeleně na kvalitu okolního prostředí [3], eliminace tvorby tepelných ostrovů [4], snížení emisní stopy oxidu uhličitého atd. Při návrhu opatření redukující vlivy klimatických změn je velmi často využíváno prvků zelené a modré infrastruktury [5]. Tato infrastruktura zahrnuje mnoho přirozených a př́rodních prvkủ jako jsou např́iklad parkové úpravy, prvky uliční zeleně, výsadba alejí, suché poldry, zelené střechy a fasády apod. 
V souvislosti s vyšším výskytem vegetačních stěn a fasád, jakožto prvků interiérů a vnějších plášt’o̊ pozemních staveb je nutno přistoupit k inženýrskému návrhu těchto prvků tak, aby splňovaly základní požadavky na stavební konstrukce a byla zajištěna jejich správná funkčnost po celou dobu životního cyklu při zajištění pouze základní údržby. Pak budou tyto prvky součástí trvale udržitelné architektury.

\section{LITERÁRNÍ PřEHLED/POPIS SOUČASNÉHO STAVU}

Vyhláška 268/2009 sb. O technických požadavcích na stavby [6] uvádí, že stavba musí být navržena a provedena tak, aby byla při respektování hospodárnosti vhodná pro určené využití a aby současně splnila základní požadavky, kterými jsou:

- Mechanická odolnost a stabilita,

- Požární bezpečnost,

- Ochrana zdraví osob a zvířat, zdravých životních podmínek a životního prostředí,

- Ochrana proti hluku,

- Bezpečnost při užívání,

- Úspora energie a tepelná ochrana.

Rozdělení vegetačních fasád dle jednotlivých systémových řešení je kvalitně popsáno v [7] a [8]. V současné době jsou vegetační fasády řešeny ve třech základních typech konstrukčního řešení. Jedná se o tyto typy:

- Systémy využívající popínavých rostlin, umístěných přímo na fasádě objektu nebo na předsazených ocelových konstrukcích,

- Systémy fasád s větranou nebo nevětranou mezerou, využívající sendvičových vegetačních panelů, umístěných na roštu z nerezových profilů kotvených do nosné konstrukce obvodového pláště objektu,

- Systémy zavěšených kapes tvořených netkanými textiliemi nebo systémy kovových nebo plastových kontejnerů zavěšených na rastru z kovových profilů. Tyto systémy jsou v současné době navrhované ve variantách jak kontaktních, tak i provětrávaných fasád.

Ahmed B. Besir shrnuje $\mathrm{v}$ přehledovém článku [9] současný stav poznání problematiky popisu vlastností a chování zelených střech a vegetačních fasád. Dobrým př́íkladem je provedené měření in situ v Barceloně, které prokázalo, že vlivem vegetační fasády dojde v letním období ke snížení teploty okolního prostředí až o $2,9^{\circ} \mathrm{C}[10]$. Vliv ozelenění jednotlivých částí pozemních staveb na jejich energetickou náročnost shrnuje B. Raji v [11]. Vliv vegetační a vodní stěny v interiéru popisuje Č́ayová v [12].

Současná literatura se zabývá nejvíce druhovým dělením vegetačních stěn a fasád, estetickými a botanickými aspekty. Dále jsou popsány konkrétní případy dopadu vegetace na zlepšení okolního prostředí. Pro možnosti inženýrského př́istupu $\mathrm{k}$ navrhování vegetačních prvků je však základním pilířem popis vlastností systémů vegetačních stěn a fasád dostupných na trhu. Na základě těch dále bude možné inženýrským způsobem prokázat již v projektové přípravě ověření požadavků vyplývajících z [6] a navazujících předpisů.

\section{METODIKA}

Vzhledem ke specifickému zadání zjištění plošné hmotnosti systémů vegetačních stěn a její změny v čase v závislosti na zálivce a evapotranspiraci bylo přistoupeno k experimentálnímu př́stupu k této problematice. Pro účely zjištění plošné hmotnosti jednotlivých systémů byl vytvořen zkušební stand. Jedná se o samostatně stojící zařízení, které umožňuje zavěšení vzorku systému vegetační fasády na předem připravenou podložku. Ta je umístěna na lineárním vedení, umožňujícím svislý pohyb vzorku v závislosti na změně hmotnosti. Podložka je dále zavěšena na tahovém tenzometru, který prostřednictvím převodníku umožňuje náhled aktuální hodnoty zatížení a dále umožňuje analogový výstup do ústředny s kontinuálním záznamem hodnot. Vzorek je dále doplněn o měřící čidla teploty a vlhkosti okolního prostředí, a to jak v bezprostřední blízkosti vegetace, tak i ve vzdálenosti $1 \mathrm{~m}$ od měřeného vzorku. Dále jsou na vzorku osazena vlhkostní čidla pro zjištění změn vlhkosti ve vegetační vrstvě. Zkušební stand je patrný na Obr. 1. 

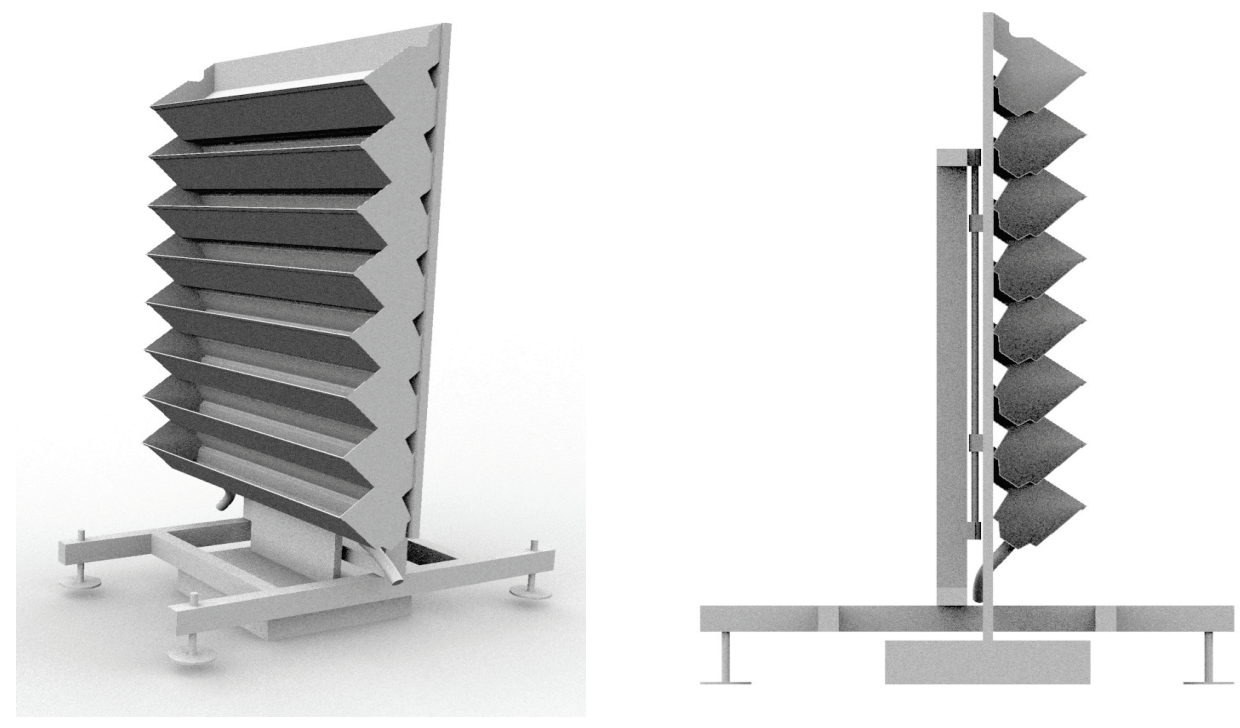

Obr. 1. Zkušební stand pro testování výsekových modelů vegetačních fasád s možností sledování dodaného množství zálivkové vody a její následný úbytek vlivem evapotranspirace.

Následně byly stanoveny podmínky, za kterých může měření probíhat. Testovaný vzorek musí být minimálně 3 týdny před začátkem měření zapěstovaný v systémových prvcích testovaného vzorku. Měrení probíhá na vzorku o minimální ploše $1 \mathrm{~m}^{2}$, za běžných podmínek při $22 \pm 3{ }^{\circ} \mathrm{C}$ a relativní vlhkosti $50 \pm 5 \%$. Pokud měření probíhá v laboratoři s přirozeným osvětlením a osluněním vzorku, je v České republice možné provádět měření od 21. 3. do 23. 9. Pokud je laboratoř a zkušební vzorek osvětlen umělým zdrojem světla, je nutné zajistit takový zdroj světla, který obsahuje dostatečné světelné spektrum, simulující denní světlo a dále nastavit osvětlení tak, aby bylo zajištěno stmívání a rozsvěcení osvitu simulující denní a noční dobu. Měření probíhá po dobu minimálně dvou týdnů nebo tak, aby byly provedeny vždy min. tři zalévací cykly zkušebního vzorku. Záznam hodnot byl zvolen v periodicitě 15 min. Př́klad měření je patrný na Obr. 2. 

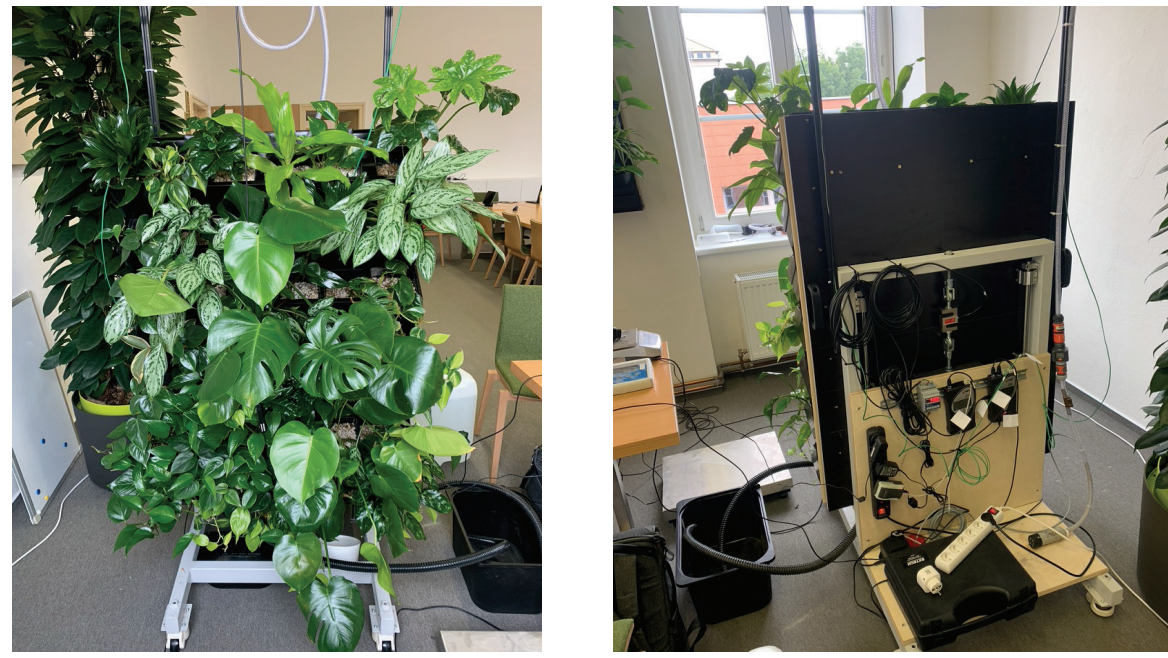

Obr. 2. Pohled na vzorek vegetační fasády, osazený na zkušebním standu.

\section{DISKUZE}

Zvolená metoda zjištění plošné hmotnosti systémů vegetačních stěn a fasád a jejích změn v čase se ukázala jako velmi účinná. Tímto měřením je možný popis jedné ze základních vlastností systémů vegetačních stěn a fasád, včetně následného porovnání jednotlivých systémů.

Výstupem experimentálního měření jsou:

- Maximální naměřená plošná hmotnost vzorku,

- Graf průběhu kolísání plošné hmotnosti v průběhu měření.

\section{ZÁVĚR}

Díky experimentálnímu testování vzorků vegetačních stěn a fasád je možný bližší popis jednotlivých systémů, jejich následná komparace $\mathrm{s}$ vyzdvihnutím výhod a nevýhod pro konkrétní př́klady použití v praxi. Díky této metodě byly zodpovězeny otázky kladené na začátku řešení projektu, dále byly zjištěny další otázky, které bude třeba řešit. Jako např́iklad měření doby setrvačnosti zálivky u průtočných systémů vegetačních fasád v závislosti na dostupné dimenzi zdroje zálivkové vody, apod.

\section{Poděkování}

Př́spěvek vznikl za podpory projektu FAST-J-21-7521 "Studium fyzikálních vlastností recyklovaných materiálů pro rozvoj jejich využitelnosti v systémech zelených fasád" a FAST-S-21-7422 "Studium tepelně vlhkostních procesů v 3D tištěných konstrukcí pozemních staveb"

\section{Použité zdroje}

[1] SCHARF, Bernahrd a Florian KRAUS. Green Roofs and Greenpass. Buildings [online]. MDPI, 2019, 2019(9), 9 [cit. 2021-12-06]. Dostupné z: https://doi.org/10.3390/buildings9090205

[2] M. LETCHER, Trevor. The impacts of climate change [online]. 1. elsevier, 2021 [cit. 2021-12-06]. ISBN 9780128223734. Dostupné z:

https://www.sciencedirect.com/science/article/pii/B9780128223734000033

[3] Chun, Bumseok a Jean-Michel Guldmann. Impact of greening on the urban heat island: Seasonal variations and mitigation strategies, [online]. 2018, 2018(71), 165-176 [cit. 2021-12-06]. ISSN 0198- 
9715. Dostupné z: https://www.sciencedirect.com/science/article/pii/S0198971517304672

[4] W L Filho, L E Icaza, A Neht, M Klavins, E A Morgan. Coping with the impacts of urban heat islands. A literature based study on understanding urban heat vulnerability and the need for resilience in cities in a global climate change context. Journal of Cleaner Production, Volume 171, 2018, Pages 1140-1149, ISSN 0959-6526. Dostupné z: https://www.sciencedirect.com/science/article/pii/S0959652617323806

[5] LAMOND, Jessica a Glyn EVERET. Sustainable Blue-Green Infrastructure: A social practice approach to understanding community preferences and stewardship. Landscape and Urban Planning [online]. 2019, 2019(191) [cit. 2021-12-06]. ISSN 0169-2046. Dostupné z: https://www.sciencedirect.com/science/article/pii/S0169204618309770

[6] Vyhláška 268/2009 Sb. O technických požadavcích na stavby. In: . Praha, 3029, ročník 209, číslo 268. Dostupné také z: https://www.zakonyprolidi.cz/cs/2009-268

[7] ENZI, V., B. CAMERON, P. DEZSÉNYI, D. GEDGE, G. MANN a U. PITHA. Nature-Based Solutions and Buildings: The Power of Surfaces to Help Cities Adapt to Climate Change and to Deliver Biodiversity. Kabisch N., Korn H., Stadler J., Bonn A. (eds), 2017. ISBN 978-3-319-53750-4.

[8] M. A. Mir BSc. Green façades and building structures. Stevinweg $12628 \mathrm{CN}$ Delft. Master thesis. Delft University of Technology, Faculty of Civil Engineering, section Materials and Environments, chair Materials \& Sustainability.

[9] B. BESIR, Ahmet a Erdem CUCE. Green roofs and facades: A comprehensive review. Renewable and Sustainable Energy Reviews [online]. 2018(82), 915-939 [cit. 2021-12-06]. ISSN 1364-0321. Dostupné z: https:/www.sciencedirect.com/science/article/pii/S1364032117313680

[10] PASCHOALINO DE JESUS, Marina, Júlia M. LOURENÇO, Rosa M. ARCE a Manuel MACIAS. Green façades and in situ measurements of outdoor building thermal behaviour. Building and Environment [online]. 2017, 2017(119), 11-19 [cit. 2021-12-06]. Dostupné z: https://www.sciencedirect.com/science/article/pii/S0360132317301506

[11] RAJI, Babak, Martin J. TENPIERIK a Andy VAN DEN DOBBELSTEEN. The impact of greening systems on building energy performance: A literature review. Renewable and Sustainable Energy Reviews [online]. 2015, 2015(45) [cit. 2021-12-06]. Dostupné z: https://www.sciencedirect.com/science/article/pii/S1364032115000994

[12] Cakyova, K.; Vertal, M.; Vystrcil, J.; Nespesny, O.; Beckovsky, D.; Rubina, A.; Pencik, J.; Vranayova, Z. The Synergy of Living and Water Wall in Indoor Environment-Case Study in City of Brno, Czech Republic. Sustainability 2021, 13, 11649. https://doi.org/10.3390/su132111649 